\title{
Maternal and perinatal outcome in eclampsia at a tertiary care center
}

\author{
Monika Dalal $^{1 *}$, Sandhya Singh ${ }^{1}$, Meenakshi Chauhan ${ }^{1}$, Smiti Nanda1, $^{1}$ \\ Jagjit Dalal'2, Shikha Madan ${ }^{1}$
}

\begin{abstract}
${ }^{1}$ Department of Obstetrics and Gynecology, Pt. B.D. Sharma Post Graduate Institute of Medical Sciences, Rohtak, Haryana, India

${ }^{2}$ Department of Neonatology, Pt. B.D. Sharma Post Graduate Institute of Medical Sciences, Rohtak, Haryana, India
\end{abstract}

\author{
Received: 12 May 2019 \\ Revised: 18 July 2019 \\ Accepted: 07 September 2019 \\ *Correspondence: \\ Dr. Monika Dalal, \\ E-mail: drmonikadalal@gmail.com
}

Copyright: () the author(s), publisher and licensee Medip Academy. This is an open-access article distributed under the terms of the Creative Commons Attribution Non-Commercial License, which permits unrestricted non-commercial use, distribution, and reproduction in any medium, provided the original work is properly cited.

\begin{abstract}
Background: Preeclampsia is the occurrence of hypertension in combination with proteinuria, developing after 20 weeks gestation in a previously normotensive non-proteinuric patient. The objective of this study was to study the prevalance of eclampsia at PGIMS, Rohtak. To study the clinical profile, maternal and perinatal outcome in eclamptic patients.

Methods: This is a retrospective study and case records of all eclampsia cases were analysed from the study period of January 2018 to December 2018.

Results: There were 113 cases of eclampsia out of 11,661 deliveries and prevalence of eclampsia was calculated to be $0.96 \%$. Majority of the patients were not registered $95.57 \% .58 \%$ of patients were Primigravidas. $56 \%$ of the patient in the age group of 21-25 years. Antepartum, intrapartum and postpartum eclampsia were $71 \%, 1.7 \%$ and $27 \%$ respectively. Caesarean section was the preferred mode of delivery and was performed in $57 \%$ cases. ICU admission was required in $25 \%$ and remaining cases were managed in general/eclampsia ward. All patients received $\mathrm{MgSO}_{4}$ by Zuspan regimen. $12 \%$ patient developed HELLP syndrome and pulmonary oedema developed in $6 \%$ patient. There were a total of $3.5 \%$ maternal deaths during the study period. Total percentage of perinatal deaths due to eclampsia was $23 \%$.

Conclusions: Eclampsia continues to be one of the prime etiological factors for maternal and perinatal morbidity and mortality. This is due to lack of proper antenatal care, low socioeconomic condition and lack of education. Regular antenatal checkup, early recognition and proper management are vital to tackle this challenge. MgSo4 is the anticonvulsant of choice and Zuspan regimen of $\mathrm{MgSO}_{4}$ is effective in the management of eclampsia.
\end{abstract}

Keywords: Blood pressure, Eclampsia, Magnesium sulphate, Morbidity

\section{INTRODUCTION}

Preeclampsia is the occurrence of hypertension in combination with proteinuria, developing after 20 weeks gestation in a previously normotensive non-proteinuric patient. Eclampsia is defined as the onset of seizure during pregnancy or postpartum in patients of preeclampsia with gestational age $>20$ weeks. The term eclampsia is derived from a Greek word meaning "lighting" or "flash of light" probably translating to its sudden and unpredictable inception. Eclampsia is life threatening complication of pregnancy. Preeclampsia (PE) and eclampsia are the second leading cause of maternal mortality claiming 46,900 deaths worldwide. ${ }^{1}$ 
Wide difference in incidence of eclampsia has been observed between developing and developed countries. ${ }^{2}$ Majority of cases of eclampsia are young primigravidas and unregistered. Preeclampsia can rapidly progress to eclampsia, especially if untreated. ${ }^{3}$

Though not all cases of eclampsia can be prevented, majority of cases can be prevented by early detection and effective treatment of preeclampsia, for which good antenatal services are needed. This study was done to analyze cases of eclampsia in relation to maternal and fetal outcomes at a tertiary level care hospital.

\section{METHODS}

This is a retrospective study and case records of all eclampsia cases were analyzed from the study period of January 2018 to December 2018 at PGIMS, Rohtak, India.

\section{Inclusion criteria}

- All the patients of eclampsia admitted during this period in PGIMS, Rohtak were included in the study.

\section{Exclusion criteria}

- Known case of seizure disorder.

This institute is a referral centre for all near and far areas of Haryana state (India), attracting a large number of patients. A total of 113 patients with eclampsia were included in this study. Pertinent information regarding the eclamptic cases was extracted from hospital inpatient records and discharge sheets. Facts collected were reconfirmed by going through operation records and delivery registers so that no cases would be missed. Information such as detailed patient profile, obstetric history, blood pressure (BP) at the time of admission, mode of delivery, duration of hospital stay including intensive care unit (ICU) admission, maternal complications and fetal outcome were noted.

The management protocol for eclampsia patients in our hospital is as follows: 1) Inj. $\mathrm{MgSO}_{4}$ was the anticonvulsant used (Zuspan regime) and 2) iv/oral labetalol was given at regular interval to achieve the desired level of systolic BP of $<160 \mathrm{mmHg}$ and diastolic BP of $<100 \mathrm{mmHg} .3$ ) Once patient was stabilized, termination of pregnancy was planned.

\section{Statistical analysis}

All data were entered in SPSS version 16 and were analyzed using simple descriptive statistics. Data were analyzed in terms of mean and percentage, and presented in tables.

\section{RESULTS}

A total of 11661 patients delivered within the study period, out of which 113 patients developed eclampsia. The prevalence of eclampsia came out to be $0.96 \%$.

Table 1: Age distribution.

\begin{tabular}{|lll|}
\hline Age group & $\begin{array}{l}\text { Number of } \\
\text { patient }\end{array}$ & $\begin{array}{l}\text { Percentage of } \\
\text { patient }\end{array}$ \\
\hline$<20$ years & 21 & $18.5 \%$ \\
\hline $21-25$ years & 63 & $55.7 \%$ \\
\hline $26-30$ years & 26 & $23 \%$ \\
\hline $30-35$ years & 3 & $2.6 \%$ \\
\hline$>35$ years & 0 & $0 \%$ \\
\hline
\end{tabular}

The age of eclamptic women in our study varied from 17 years to 32 years (Table 1). Eclampsia was found to be more common in young patients with age $<25$ years $(74.2 \%)$.

Table 2: Booking status.

\begin{tabular}{|lll|}
\hline Booking status & $\begin{array}{l}\text { Number of } \\
\text { patients }\end{array}$ & $\%$ \\
\hline Booked & 5 & $4.43 \%$ \\
\hline Unbooked & 108 & $95.57 \%$ \\
\hline
\end{tabular}

95.5\% of women managed for eclampsia were unbooked (Table 2). Only one woman who suffered with eclampsia had completed four ante-natal check-up (ANC) visit as recommended by national protocol.

Table 3: Parity.

\begin{tabular}{|lll|}
\hline Parity & $\begin{array}{l}\text { Total number } \\
\text { of patient }\end{array}$ & $\begin{array}{l}\text { Percentage of } \\
\text { patient }\end{array}$ \\
\hline Primigravida & 65 & $57.5 \%$ \\
\hline Multigravida & 48 & $42.5 \%$ \\
\hline
\end{tabular}

Maximum patient $57.5 \%$ were primigravida in our study (Table 3).

Table 4: Timing of convulsion.

\begin{tabular}{|lll|}
\hline $\begin{array}{l}\text { Timing of } \\
\text { convulsion }\end{array}$ & $\begin{array}{l}\text { Total number } \\
\text { of patient }\end{array}$ & $\begin{array}{l}\text { Percentage of } \\
\text { patient }\end{array}$ \\
\hline Antepartum & 80 & $70.7 \%$ \\
\hline Intrapartum & 2 & $1.7 \%$ \\
\hline Postpartum & 31 & $27.4 \%$ \\
\hline
\end{tabular}

$71 \%$ patient had antepartum eclampsia and only $27 \%$ had postpartum eclampsia (Table 4).

$43 \%$ patient were in between gestational age group of more than 36 weeks and only $3.5 \%$ patients were $<25$ week (Table 5). 
Table 5: Gestational age distribution.

\begin{tabular}{|lll|}
\hline $\begin{array}{l}\text { Gestational } \\
\text { age }\end{array}$ & $\begin{array}{l}\text { Number of } \\
\text { patient }\end{array}$ & $\begin{array}{l}\text { Percentage of } \\
\text { patient }\end{array}$ \\
\hline 21-25 weeks & 4 & $3.5 \%$ \\
\hline $26-30$ weeks & 12 & $10.6 \%$ \\
\hline $31-35$ weeks & 32 & $28.3 \%$ \\
\hline $36-40$ weeks & 36 & $31.8 \%$ \\
\hline$>40$ weeks & 13 & $11.5 \%$ \\
\hline
\end{tabular}

Table 6: Convulsion delivery-interval.

\begin{tabular}{|lll|}
\hline $\begin{array}{l}\text { Convulsion-delivery } \\
\text { interval }\end{array}$ & $\begin{array}{l}\text { Number } \\
\text { of patient }\end{array}$ & $\begin{array}{l}\text { Percentage of } \\
\text { patient }\end{array}$ \\
\hline 1hour-10hour & 78 & $97.5 \%$ \\
\hline$>10$ hour & 2 & $2.5 \%$ \\
\hline
\end{tabular}

Convulsion-delivery interval is the interval between first eclamptic fit and the time of delivery. Maximum patient $(97.5 \%)$ had convulsion delivery interval between 1 hour10 hour (Table 6).

Table 7: B. P. at the time of presentation.

\begin{tabular}{|c|c|c|}
\hline $\begin{array}{l}\text { BP at the time of } \\
\text { admission }\end{array}$ & Number (n) & $\%$ \\
\hline \multicolumn{3}{|l|}{ Systolic (mmHg) } \\
\hline Less than 140 & 20 & $17.79 \%$ \\
\hline $140-160$ & 71 & $62.84 \%$ \\
\hline More than 160 & 22 & $19.47 \%$ \\
\hline \multicolumn{3}{|l|}{ Diastolic (mmHg) } \\
\hline Less than 90 & 16 & $14.15 \%$ \\
\hline $90-110$ & 73 & $64.62 \%$ \\
\hline More than 110 & 24 & $21.23 \%$ \\
\hline
\end{tabular}

BP noted at the time of admission was categorized in terms of systolic and diastolic. Systolic blood pressure (SBP) was more in the range of $140-160 \mathrm{mmHg}$ accounting $62.8 \%$ followed by $>160 \mathrm{mmHg}$ in $19.4 \%$ and $<140 \mathrm{mmHg}$ in $17.7 \%$. Diastolic blood pressure (DBP) was noted to be $<90 \mathrm{mmHg}$ in $14.15 \%, 90-110 \mathrm{mmHg}$ in $64.62 \%$ and $>110 \mathrm{mmHg}$ in $21.23 \%$ (Table 7 ).

Table 8: Mode of delivery.

\begin{tabular}{|lll|}
\hline $\begin{array}{l}\text { Mode of } \\
\text { delivery }\end{array}$ & $\begin{array}{l}\text { Number of } \\
\text { patient }\end{array}$ & $\begin{array}{l}\text { Percentage of } \\
\text { patient }\end{array}$ \\
\hline LSCS & 65 & $57.5 \%$ \\
\hline Vaginal & 45 & $39.8 \%$ \\
\hline Instrumental & 3 & $2.6 \%$ \\
\hline
\end{tabular}

Out of 113 eclamptic patients, 65 women underwent caesarean section (CS) and 3 had instrumental delivery using either forceps or ventouse. Remaining 45 women delivered vaginally which also embraced 6 home deliveries. Cesarean delivery was the common mode of delivery in $57 \%$ of the patient (Table 8). The most common indication of cesarean was fetal distress.
Total maternal deaths were $3.5 \%$. DIC occurred in 1 patient, HELLP syndrome developed in 14 patients, pulmonary edema developed in 7 patients and intracranial hemorrhage occurred in 1 patient (Table 9).

Table 9: Maternal outcome.

\begin{tabular}{|lll|}
\hline $\begin{array}{l}\text { Maternal } \\
\text { complication }\end{array}$ & $\begin{array}{l}\text { Total number } \\
\text { of patient }\end{array}$ & $\begin{array}{l}\text { Percentage } \\
\text { of patient }\end{array}$ \\
\hline DIC & 1 & $0.88 \%$ \\
\hline HELLP & 14 & $12.3 \%$ \\
\hline Pulmonary oedema & 7 & $6.1 \%$ \\
\hline $\begin{array}{l}\text { Intracranial } \\
\text { hemorrhage }\end{array}$ & 1 & $0.88 \%$ \\
\hline
\end{tabular}

ICU admission was mandated in $24.8 \%$ women. Rest $75.2 \%$ women were managed in the eclampsia room and general wards depending on the patients' status (Table 10). Cause of death was pulmonary edema in 2 patients, HELLP syndrome in one patient and unidentifiable cause in one patient.

Table 10: Hospital stay.

\begin{tabular}{|lll|}
\hline Place of admission & $\begin{array}{l}\text { No. of } \\
\text { patients }\end{array}$ & Percentage \\
\hline ICU admission & 28 & $24.77 \%$ \\
\hline $\begin{array}{l}\text { Ward admission/ eclampsia } \\
\text { room }\end{array}$ & 85 & $75.22 \%$ \\
\hline
\end{tabular}

Out of 113 babies $80.5 \%$ babies were live born and $19.5 \%$ were still born (Table 11). Total percentage of perinatal deaths due to eclampsia was $23 \%$. Out of 91 live births, 45 (49.4\%) babies admitted to NICU and 4 (4.3\%) babies had neonatal death. Despite born to an eclamptic mother $87(76.9 \%)$ newborns were apparently normal.

Table 11: Perinatal outcome.

\begin{tabular}{|lll|}
\hline $\begin{array}{l}\text { Perinatal } \\
\text { outcome }\end{array}$ & $\begin{array}{l}\text { Total number of } \\
\text { birth }\end{array}$ & $\begin{array}{l}\text { Percentage of } \\
\text { birth }\end{array}$ \\
\hline $\begin{array}{l}\text { Total live } \\
\text { birth }\end{array}$ & 91 & $80.5 \%$ \\
\hline $\begin{array}{l}\text { Total still } \\
\text { birth }\end{array}$ & 22 & $19.5 \%$ \\
\hline
\end{tabular}

\section{DISCUSSION}

The overall prevalence of eclampsia in our study was 9.6 per 1000 deliveries. Similar prevalance was reported other studies. The incidence of eclampsia was reported as 5.8 per 1000 deliveries by Shaikh SB et al and 10 per 1000 deliveries by Sunita TH et al. ${ }^{4,5}$

In a study conducted at a tertiary centre in Kathmandu the prevalence was calculated to be 1.4 per 1000 deliveries. $^{6}$ Diversity in prevalence has been detected in various studies. $^{7,8}$ The frequency is significantly lower in developed 
countries and may be credited to effective antenatal services. ${ }^{7,9-11}$ Prominent rates of eclampsia at our setting may be related to high referrals received from urban health centers, primary health centers, rural hospitals, sub district hospitals and also from private hospitals.

Eclampsia was more commonly seen in young pregnant women up to 25 years $(74 \%)$ and primigravidas $(57 \%)$. Similar findings were observed by Shaikh S B et al and Acharya $\mathrm{G}$ et al.,12 Gautam (Bhattarai) SK et al found $61.3 \%$ of their study sample were primigravida. ${ }^{13}$ So, there should be compulsory and regular screening of young pregnant woman especially primigravida for preeclampsia/eclampsia. The outcome is substantially dissimilar with result noted by Duckitt et al and Berhe et al who have identified advancing maternal age as a risk factor for eclampsia. ${ }^{11,14}$

All $80.2 \%$ of patients were not registered and around $15.4 \%$ of patients had some sort of antenatal care at primary health center or subcentre and $4.4 \%$ were booked and registered either at our hospital or other tertiary care or private hospital. Lack of antenatal care is a serious concern and one of the important risk factors for the development of eclampsia. ${ }^{15-17}$ Ghimire S, Reported that $97 \%$ of eclampsia patients did not receive antenatal check-up. ${ }^{18}$ Duhan L et al found $96 \%$ of cases were unbooked.

There were $71 \%$ of eclampsia were antepartum, $2 \%$ were intrapartum and $7 \%$ were postpartum. Similar observation was noticed in other studies as well. Chaudhary P, found antepartum eclampsia in $70 \%$ of her patients had, Ghimire S, found it in $83 \%$ of cases. ${ }^{18,19}$ Comparable findings were found in other studies. ${ }^{20}$ In contrast to our finding Douglas et al reported higher incidence of postpartum eclampsia in the UK which could be due to good ANC surveillance. ${ }^{9}$ Ecalmpsia was seen in $43 \%$ of patients at term gestation in our study which is similar to a study done by Marinakhanum et al, i.e $53 \% .^{21}$

Level of BP is crucial in defining pre-eclampsia and eclampsia. ${ }^{22}$ SBP of $140 \mathrm{mmHg}$ or more and DBP of 90 $\mathrm{mmHg}$ or more is considered as cut-off level. ${ }^{11}$ In our study $14 \%$ patients had normal BP recording at presentation. Mattar F et al, quoted $16 \%$ of the patients had no hypertension. ${ }^{23}$ We found SBP more than $160 \mathrm{mmHg}$ in $19.47 \%, 140-160 \mathrm{mmHg}$ in $62.84 \%$ and less than $140 \mathrm{mmHg}$ in $17.79 \%$. Study conducted by Jha et al who had SBP of more than $160 \mathrm{mmHg}$ in $18 \%, 140-$ $160 \mathrm{mmHg}$ in $36 \%$ and less than 140 in $46 \% .^{20} \mathrm{DBP}$ of more than $90 \mathrm{mmHg}$ was noted in $85.8 \%$ cases similar to finding of Rana et al who noted it to be $92 \% .{ }^{24}$ Vaginal was a common mode of delivery in our series $(56 \%)$ which is similar to study done by Sibai BM et al. ${ }^{25}$ Eclampsia per se is not an indication for cesarean section and mode of delivery had no significant effect on the outcome of the eclamptics as per Ibrahim A et al. ${ }^{26}$ Judicious and timely selection of cases for either vaginal delivery or cesarean section is going to improve the maternal and perinatal outcome.
Our study reveals that CS was performed in $57.5 \%$ of eclamptic women and $25 \%$ required ICU care. The rate of cesarean section is comparable to other studies. The percentage of cesarean section required in eclamptic women was reported $55.31 \%$ by Chaudhary $\mathrm{P}$ et al, and $45 \%$ by Sunita $\mathrm{TH}$ et al. ${ }^{5,19}$ Risk of medical litigation and taking no-risk policy adds to rising CS rate. Kurude et al, reported vaginal delivery $(56 \%)$ as a common mode of delivery. ${ }^{27}$

The proportion of patients required intensive care in our study is similar to observation made by Ghimire $\mathrm{S}$ who reported that $29.46 \%$ of patients required intensive care in her study. ${ }^{18}$ These findings warrant need of urgent referral to tertiary care centre in case of women with eclampsia. All our patients received $\mathrm{MgSO}_{4}$ as per Zuspan regimen to prevent convulsions. Recurrence of fits increases the maternal morbidity. ${ }^{28}$ Efficacy of $\mathrm{MgSO}_{4}$ in prevention and treatment of eclamptic convulsions is time tested, however narrow therapeutic index and toxicity is still a major concern in clinical use. Respiratory rate, patellar reflex, urine output should be monitored strictly. ${ }^{29}$

There were $3.5 \%$ maternal death due to eclampsia, the most common causes of maternal death are HELLP, acute renal failure secondary to abruption placentae, DIC. Similar findings were reported in other studies done in Nepal and in India. Kurude et al reported 5.3\% maternal death in eclampsia patients. ${ }^{27}$ Similar maternal outcome was mentioned by Sunita TH, Ghimre S and Shakya et al., 5,,18

There were $19.5 \%$ still born and out of $80.5 \%$ live babies $4.3 \%$ babies had neonatal death. The most common causes of perinatal death were prematurity, fetal growth restriction, fetal asphyxia and acidosis. In half number of newborn, Apgar score at 5 minutes was less than 7 . There were total $5(10.85 \%)$ fetal deaths observed in our study i.e. three $(6.5 \%)$ were still born and $2(4.35 \%)$ were macerated babies. Many studies have suggested that there is higher risk of preterm delivery and low birth weight in eclampsia along with increased rate of fetal death. ${ }^{18,19,30,31}$

\section{CONCLUSION}

The study concluded that eclampsia continues to be one of the prime etiological factor for maternal and fetal morbidity and mortality. This is mainly due to lack of proper antenatal care, lack of education and low socio economic condition.

According to the Royal College of Obstetricians and Gynaecologists (RCOG) good antenatal services will detect and treat preeclampsia and thus reduce the incidence of eclampsia. There is an urgent need for proper antenatal care and timely hospitalization to reduce the maternal and perinatal morbidity and mortality. Appropriate steps are to be taken regarding proper antenatal care by the government to tackle with the menace of eclampsia. 
Funding: No funding sources

Conflict of interest: None declared

Ethical approval: Not required

\section{REFERENCES}

1. Wang H, Naghavi M, Allen C, Barber R, Bhutta Z, Carter A et al. Global, regional, and national life expectancy, all-cause mortality, and cause-specific mortality for 249 causes of death, 1980-2015: a systematic analysis for the Global Burden of Disease Study 2015. Lancet. 2016;388(10053):1459-544.

2. Berhe AK, Kassa GM, Fekadu GA, Muche AA. Prevalence of hypertensive disorders of pregnancy in Ethiopia: a systemic review and meta-analysis. BMC Pregnancy Childbirth. 2018;18:34.

3. Mahmoudi N. Eclampsia: a 13-year experience at a United States tertiary care center. J Womens Health Gender Based Med. 1999;8:495-500.

4. Shaikh SB, Jampala S, Devi S, Mallika. A study on maternal and perinatal out comes in cases of eclampsia admitting to government medical college and general hospital, Anantapuramu, Andhra Pradesh, India. Int J Reprod Contracept Obstet Gynecol. 2016;5(7):2146-50.

5. Sunita $\mathrm{TH}$, Desai RM. Eclampsia in a Teaching Hospital: Incidence, clinical profile and response to Magnesium Sulphate by Zuspan's regimen. J Dent Med Sci. 2013;4(2):1-5.

6. Shakya B, Vaidya A. Overview of eclampsia at a tertiary care hospital. NJOG. 2013;8(2):46-9.

7. Das R, Biswas S. Eclampsia: The major cause of maternal mortality in eastern India. Ethiop J Health Sci J. 2015;25(2):111.

8. Chaturvedi S, Randive B, Mistry N. Availability of treatment for eclampsia in public health institutions in Maharashtra, India. J Health Popul Nutr. 2013;31(1);8695.

9. Douglas KA, Redman CWG. Eclampsia in the United Kingdom. BMJ. 1995;50(7):499-500.

10. Say L, Chou D, Gemmill A, Tunçalp Ö, Moller A, Daniels J, et al. Global causes of maternal death: a WHO systematic analysis. Lancet Glob Health. 2014;2(6):323-33.

11. Berhe AK, Kassa GM, Fekadu GA, Muche AA. Prevalence of hypertensive disorders of pregnancy in Ethiopia: a systemic review and meta-analysis. BMC Preg Childbirth. 2018;18:34.

12. Acharya G, Schultz S. Eclampsia in Patan hospital: a two year retrospective study. J Nepal Med Asso. 1991;29:254-8.

13. Gautam (Bhattarai) SK, Paudel K, Silwal K. Management and Outcome of Pre-eclampsia/Eclampsia among patient admitted in maternity ward in tertiary hospital. J Inst Med. 2013;35:2.

14. Duckitt K, Harrington D. Risk factors for pre-eclampsia at antenatal booking: systematic review of controlled studies. BMJ. 2005;330(7491):565.
15. Andersgaard AB, Herbst A, Johansen M. Eclampsia in Scandinavia: incidence, substandard care, and potentially preventable cases. Acta Obstet Gynecol Scand. 2006; 85(8):929-36.

16. Swain S, Ohha KN, Prakash A. Maternal and perinatal mortality due to eclampsia. Indian Pediatr. 1993;30(6):771-3.

17. Abbade JF, Roberto A, Costa A, Anice MVC, Vera $\mathrm{TM}$, Marilza VC, et al. Scheme versus an alternative magnesium sulfate scheme: randomised clinical trial of magnesium serum concentrations. Hyper Preg. 2010;29(1):82-92.

18. Ghimire S . Eclampsia: feto-maternal outcomes in a tertiary care centre in Eastern Nepal. J Nepal Med Assoc. 2016;54(201):24-8.

19. Choudhary P. Eclampsia: A hospital based retrospective study. Kathmandu Univ Med J. 2003;1(4):237-41.

20. Jha R, Verma S, Jha SK. Eclampsia in Janakpur zonal hospital, Nepal: Favourable outcome with Magnesium sulphate. N J Obstet Gynaecol. 2007;2(1):16-9.

21. Khanum M, Ashraf F, Sahrin H. A clinical study of 100 cases of eclampsia in Rajshahi Medical College Hospital. TAJ. 2004;17(2):80-3.

22. Bushnell C, Chireau M. Preeclampsia and stroke: Risks during and after pregnancy. Stroke Res and Treat. 2011;2011:1-9.

23. Mattar F, Sibai BM. Eclampsia. VIII. Risk Factors for maternal morbidity. Am J Obstet Gynecol. 1990;163:1049-55.

24. Rana S, Kattel P. Eclampsia at a tertiary care hospital of Nepal: A five year study. Janaki Med College J Med Sci. 2018;6(2):14-21.

25. Sibai BM. Diagnosis and management of gestational hypertension and preeclampsia. Obstet Gynecol. 2003;102:181-92.

26. Yakasai IA, Gaya SA. Maternal and fetal outcome in patients with eclampsia at Murtala Muhammad specialist Hospital Kano, Nigeria. Ann Af Med. 2011;10:4.

27. Kurude VN, Kokate PH, Saha D, Jha EK. Study of maternal and perinatal outcome in eclampsia. Paripex Ind J Res. 2017;6(4):63-5.

28. Witlin AG, Sibai BM. Magnesium sulfate therapy in preeclampsia and eclampsia. Obstet Gynecol. 1998;92(5):883-9.

29. Witlin AG. Prevention and treatment of eclamptic convulsions. Clin Obstet Gynecol. 1999;42(3):507-18.

30. Duhan L, Nanda S, Dahiya P, Chaudhary S. Sociodemographic profiling and study of maternal and perinatal outcome in patients suffering from eclampsia. Int J Reprod Contracept Obstet Gynecol. 2016;5(6):1870-3.

31. Pokharel N, Shrestha M, Regmi M. Maternal, fetal and new born outcomes in pre-eclampsia and eclampsia: a hospial based study. Health Renais. 2014;12(2):106-10.

Cite this article as: Dalal M, Singh S, Chauhan M, Nanda S, Dalal J, Madan S. Maternal and perinatal outcome in eclampsia at a tertiary care center. Int J Reprod Contracept Obstet Gynecol 2019;8:3898-02. 